\title{
Emulsion and inulin stability of meat pate with reduced fat content as a function of sterilization regimes
}

\author{
Maria Marianovna MOMCHILOVA ${ }^{1}$ Todorka Valkova PETROVA ${ }^{1}$, Dilyana Nikolaeva GRADINARSKA-IVANOVA², \\ Dinko Georgiev YORDANOV²* (D)
}

\begin{abstract}
The paper examines the effect of eleven sterilization regimes on the emulsion capacity and achieved lethal effect of sterilized meat pâte with reduced fat content and addition of inulin. The changes in the inulin-type fructan content were traced under the different sterilization conditions. Optimal Central Composite Design (OCCD) was adopted to study, as independent variables of the sterilization process are selected: temperature and holding time. The mathematical models obtained describe with relatively high accuracy the effect of temperature and holding time of sterilization on the emulsion stability, the residual fructan content and the factual lethality during the sterilization process. It was found that the increase of the sterilization duration of the pâtés was responsible to a larger extent for the reduction of their emulsion stability whereas the rise in temperature had a more significant effect on their residual fructan quantity.
\end{abstract}

Keywords: canned meat; lethal effect; emulsion stability; inulin-type fructans.

Practical Application: The obtained results and models are important for the development of sterilization modes for the production of low-fat meat emulsion and meat systems enriched with inulin.

\section{Introduction}

Meat pâtés are emulsion-type meat products with high fat content. Fat reduction or removal is desirable with regard to its connection to a number of health issues the human society, such as cardio-vascular diseases (Briggs et al., 2017; Olmedilla-Alonso et al., 2013). Fats, however, have a stabilizing effect on the emulsion formed by the extracted meat proteins, thereby contributing to improve consistency and juiciness (Choi et al., 2009, 2013; Morin et al., 2004) and the taste characteristics of the product (Santhi et al., 2017). Their positive role in the reduced contraction of the protein net during the heat treatment of the meat mass has also been confirmed (Feiner, 2006; Kumar et al., 2016). Therefore, the choice of components for fat substitution in meat emulsion products is of great importance. Prebiotic inulin is a functional food ingredient that has a future in this respect (Berizi et al., 2017; Mantzouridou et al., 2012; Shoaib et al., 2016; Souza et al., 2019). Regardless of the undoubtedly proven texturizing properties of inulin, there are different opinions in scientific literature concerning its use for the stabilization of the raw and thermally processed meat mass in the manufacture of meat products. According to Felisberto et al. (2015) prebiotic fibers as well as inulin when are used as fat substitutes reduce stability of meat emulsions and increased the gelation temperature of the new complex low-fat meat structure. At the emulsification process inulin improved the water binding and the stability of the meat batter, but during heat treatment its ability to retain bound water decreases (Silva-Vazquez et al., 2018). The obtained models by Keenan et al. (2014) showed that inulin inclusion as fat replacement in comminuted meat products reduced cook loss and improved emulsion stability, but also led to significant modification in textural and eating quality of final product. Therefore, the direct effect of inulin preparations on the indicators of texture (Álvarez \& Barbut, 2013; Cegielka \& Tambor, 2012) along with consumers' growing demand for healthier meat products provide an interesting opportunity for improving the food profile of these products. This is particularly valid for sterilized meat pâtés where the effect of high-temperature processing on the emulsifying capacity of the modified composition of the meat matrix has been insufficiently studied. Therefore, the aim of this work was to study the effect of the independent variables (temperature and holding time) of the sterilization process upon the lethal effect, emulsion stability and inulin-type fructan content of low fat pâtés.

\section{Materials and methods}

Pâté recipe: The following ingredients were used for the production of the meat pâté: deboned turkey meat: $30 \%$, chicken liver: $10 \%$, egg mélange: $18 \%$, inulin: $12.5 \%$, pork soft fat: $11.25 \%$, cornstarch: $2 \%$, lentil flour: $1.25 \%$, table salt: $1.5 \%$, sodium nitrite: $0.005 \%$, polyphosphates: $0.2 \%$, black pepper: $0.3 \%$, nutmeg: $0.05 \%$, coriander: $0.15 \%$, and potable water: $15 \%$. Orafti ${ }^{\circledR} \mathrm{HPX}$ inulin (Beneo-Orafti Ltd., Belgium) was used in the form of a 
gel obtained by hydration as described by Latoch et al. (2016), and was added during the cutting process.

Pâté processing: Experimental pâtés were prepared from defrosted and sliced poultry meat by grinding in a cutter (Fimar CL/5) and with addition of poultry liver. During the cutting curing salts, polyphosphates, egg mélange, spices, inulin and lentil flour were added. During the cutting, water was added up to $15 \%$ by weight of the meat. The prepared fine and homogenous meat mixture was heated to $70^{\circ} \mathrm{C}$ and filled manually into cans having a size of $\mathrm{H}=26.5 \mathrm{~mm}$ and $\mathrm{D}=99 \mathrm{~mm}$.. Cans were closed with sealing machine (Lanico Machinenbau, Otto Niemsch $\mathrm{KG}$, Braunschweig) and sterilized in the laboratory autoclave at eleven different sterilization regimes (Table 1).

The emulsion stability was determined according to the method described by Zorba et al. (1993).

For determination of residual fructans (including inulin) in the samples, a spectrophotometric method based on the Seliwanoff Reaction for ketoses was used (Petkova et al., 2014).

\subsection{Experimental design and data analysis}

The statistical processing of the data obtained was made using the Statgraphics 16 software. The experiments were conducted with threefold repetition, and the data in the tables and graphs are arithmetic means of the indicators measured. Statistically significant differences were found at a probability less than 0.05 .

Optimal Central Composite Design (OCCD) was used for the sterilization of low fat pâtés according to response surface methodology with two variables (Table 1), (Riswanto et al., 2019). The complete design consisted of 11 experimental runs with three replications of the center point. The levels of the independent variables (temperature and holding time) were established according to literature information and preliminary trials.
Considering two parameters and a response, the experimental data were fitted to obtain a second-degree regression Equation 1 of the form:

$y=b_{0}+\sum_{i=1}^{n} b_{i} X_{i}+\sum_{i=1}^{n} b_{i i} X_{i}^{2}+\sum_{i=1}^{n} \sum_{j=1}^{n} b_{i j} X_{i} X_{j}$

where $y$ is the predicted response (dependent variable) for lethal effect, emulsion stability and inulin-type fructan content, respectively; $X_{i}$. and $X_{i}$ are the independent variables; $b_{0}, b_{i}, b_{i i}$, $b_{\mathrm{ij}}$ are regression coefficient for intercept, linear, quadratic and interaction terms. SYSTAT statistical software (SPSS Inc., Chicago, USA, version 7.1) and Excel (Microsoft Office, 97-2003) were used to analyze the data.

\section{Results and discussion}

The thermograms during sterilization of the pâté samples are shown in Figure 1. The heat sterilization regimes of canned poultry meat should both maintain the highest possible organoleptic parameters and ensure the microbiological safety of the product. From this point of view, it is particularly relevant to work out a formula for sterilizing new types of canned food with poultry meat (Pasichnyi et al.,2017). From the data of Table 1, it can be concluded that the sterilization modes of sample 2, sample 4 , sample 6 , and sample 8 are sufficient to ensure the commercial sterility of cans (Holdsworth \& Simpson, 2016).

The regression models for all the investigated responses were highly significant (according to P-value) with satisfactory coefficients of determination $\left(R^{2}\right)$ in the range of $0.9930-0.9986$ (Equations 2, 3, and 4). These results show that the predicted models for the investigated responses were adequate, indicating that the second-order polynomial model could therefore be effectively used to represent the relationship between the selected parameters (Jozinović et al., 2017; Pietrasik \& Li-Chan, 2002).

Table 1. Optimal central composite design and experimental data for lethal effect, emulsion stability and inulin-type fructan content of low fat pâtés sterilized under different conditions.

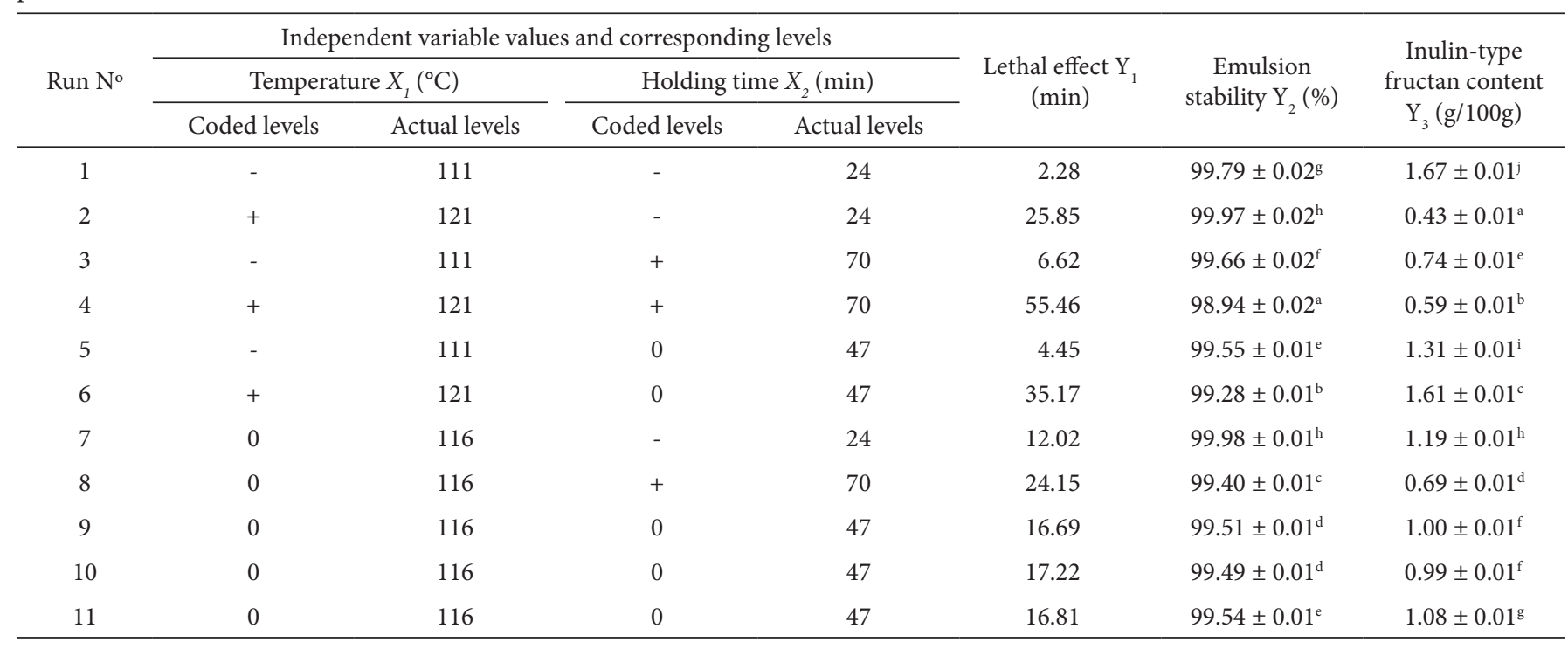

The values shown are the arithmetic means of three measurements for each indicator for the respective sample. a-j - the values bearing a common letter designation did not differ statistically $(\mathrm{P}>0.05)$. 

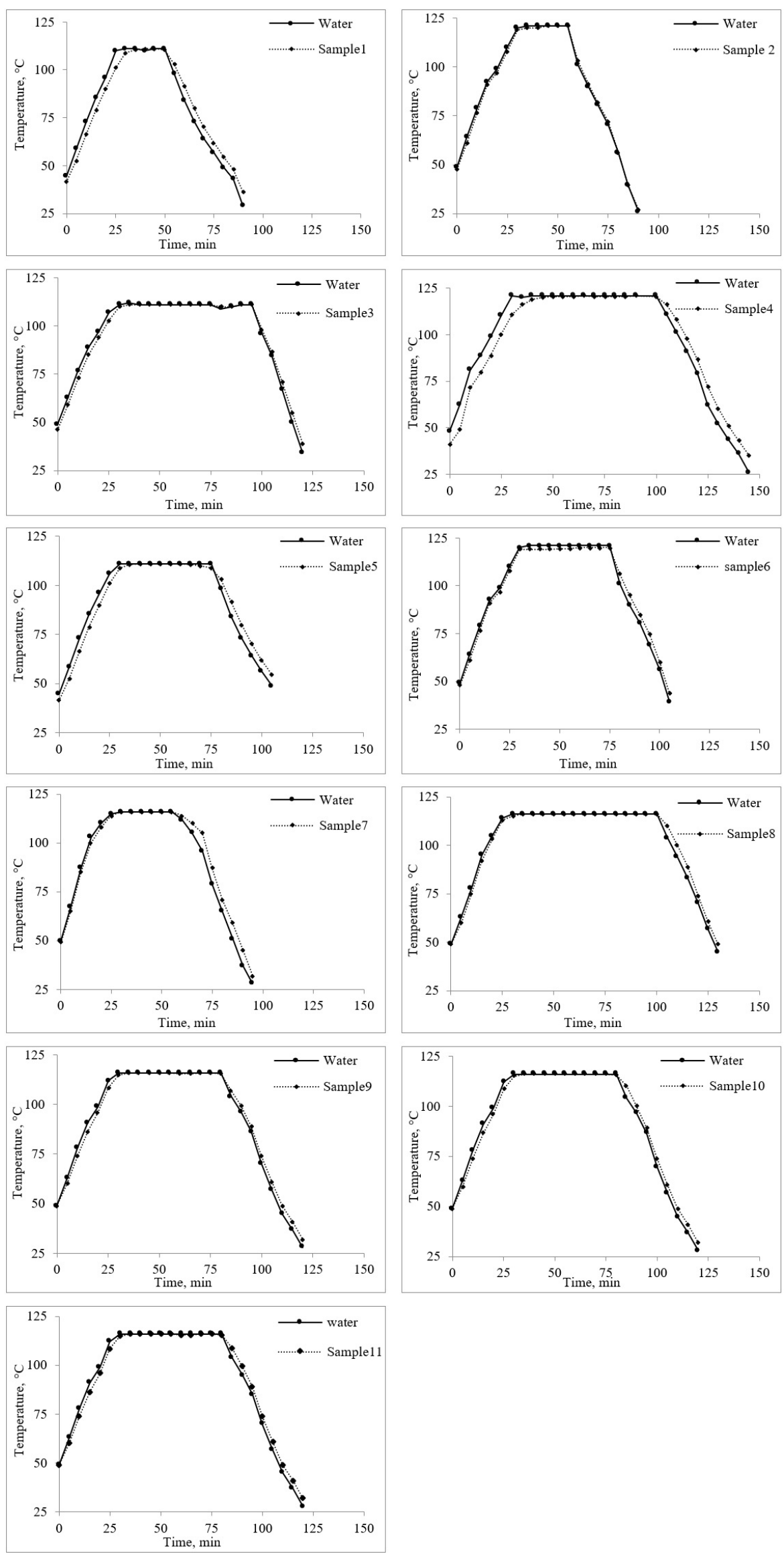

Figure 1. Heating curves of the pâté samples under different sterilization conditions. 
The resulting models, after removing the nonsignificant terms, were evaluated in terms of uncoded factors and are presented below:

$$
\begin{aligned}
& Y_{1}=700.466-12.638 X_{1}-6.724 X_{2}+0.055 X_{1} X_{2}+0.008 X_{2}^{2}\left(R^{2}=0.9938\right) \\
& Y_{2}=39.906+0.986 X_{1}+0.183 X_{2}-0.004 X_{1}^{2}-0.002 X_{1} X_{2}+0.0003 X_{2}^{2}\left(R^{2}=0.9986\right) \\
& Y_{3}=-17.448+0.5 X_{1}-0.267 X_{2}-0.003 X_{1}^{2}+0.002 X_{1} X_{2}-0.0002 X_{2}^{2}\left(R^{2}=0.9930\right)
\end{aligned}
$$

Each of the estimated effects and interactions are shown in the standardized diagram, the Pareto chart (Figure 2). It consists of horizontal blocks with lengths proportional to the absolute values of the estimated effects, divided by their standard errors. The vertical line in the Pareto chart represents the value of the Student criterion at $95 \%$ confidence level and separates factors that are significant from those that are not.

The Pareto chart for emulsion stability (Figure 2a) shows the predominance of holding time (factor $\mathrm{B})$. The interaction between temperature and holding time $(\mathrm{A} \times \mathrm{B})$ comes next in order of importance. Temperature (factor A) also had a significant effect on emulsion stability. In total, there were five statistically significant effects. With the increase in treatment

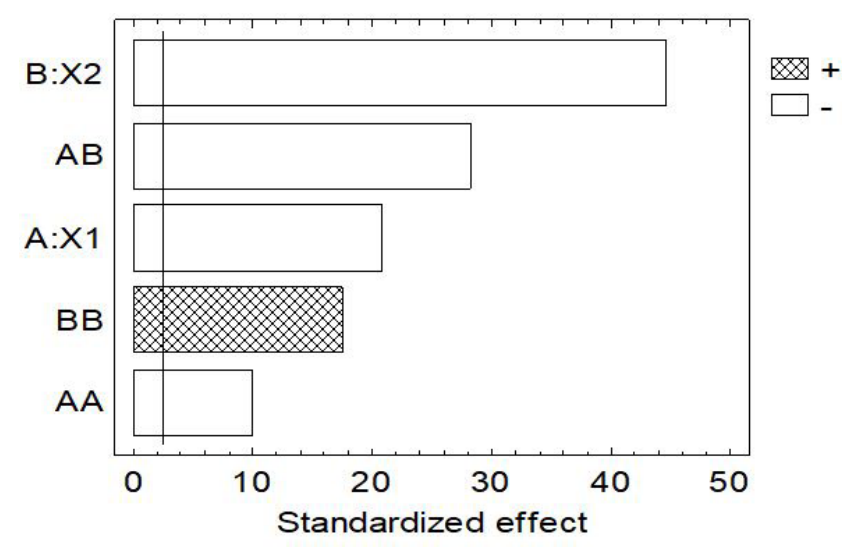

a

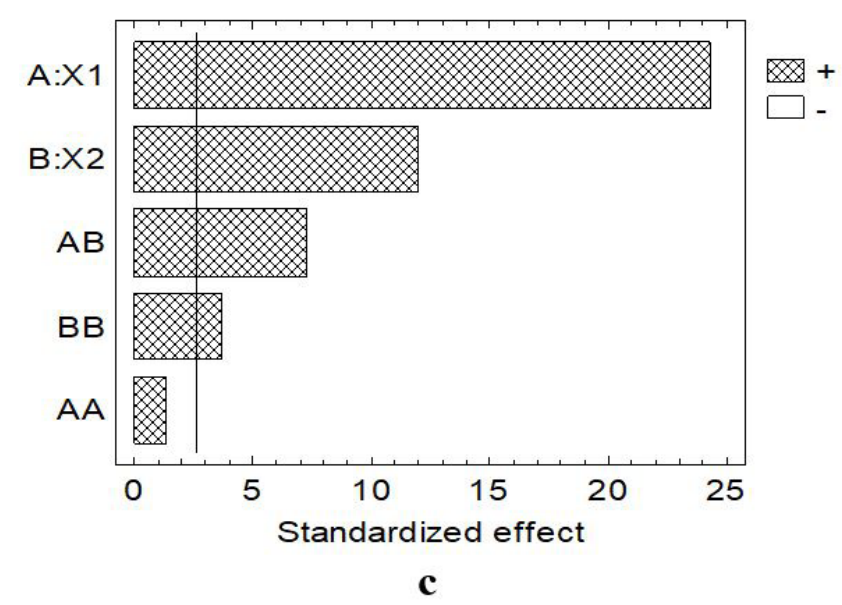

time, emulsion stability decreased. The same trend was observed with temperature.

The linear effect that was due to the temperature (factor A) had the highest impact on the inulin-type fructan content (Figure 2b). The holding time (factor B) also had a significant effect on the inulin-type fructan content $(\mathrm{P}<0.05)$. Fructans decreased with the increase in temperature. The same trend was observed with treatment time.

The linear effect that was due to the temperature (factor A) had the highest impact on the lethal effect (Figure 2c), followed by the holding time (factor B). The L-values increased with the increase in temperature. They also increased with the increase in holding time but to a lesser extent. Predictably, higher factual lethality values (L-values) in pâté sterilization were reached as a result of the combination between high temperature and long pate sterilization time (Figure $3 \mathrm{c}$ ).

The best way to visualize the effect of independent variables on dependent ones is to draw surface response plots of a proposed model like those given in Figure 3, which shows the combined effects of process variables (temperature and holding time) on lethal effect, emulsion stability, and inulin-type fructan content of pâté samples. The variation of responses with respect to different factor levels can be seen in the surface plots for each response (Luckose et al., 2015). As holding time increased from 24 to $70 \mathrm{~min}$ and temperature from 111 to $121{ }^{\circ} \mathrm{C}$, both responses

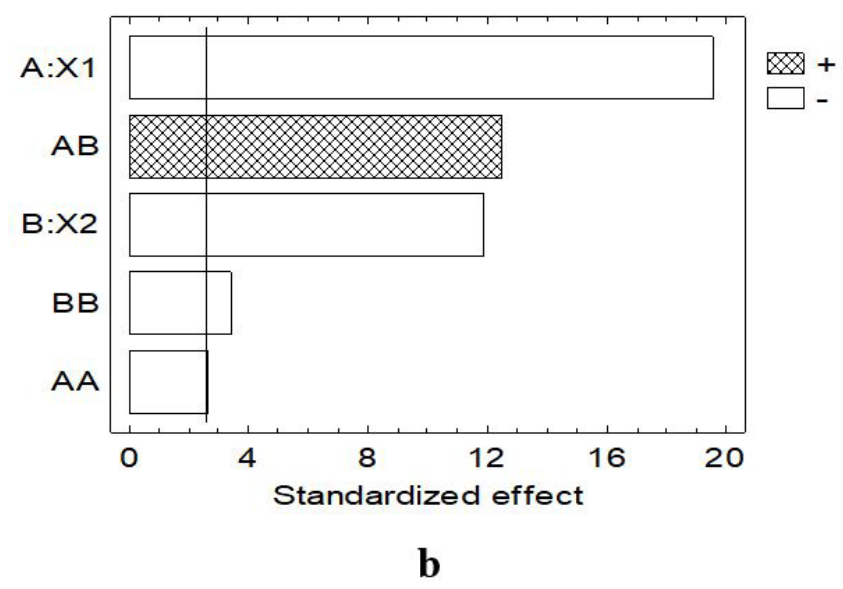

Figure 2. Estimated effects of regression model coefficients on the emulsion stability (a), inulin-type fructan content (b) and lethal effect (c). 
namely emulsion stability and inulin-type fructan content, were found to decrease (Figure 3a, b). The lowest emulsion stability value of $98.94 \%$ was recorded in the sample with the longest sterilization time and the highest treatment temperature (the upper levels of the independent variables), which was statistically different $(P<0.05)$ from all other samples (Table 1, Figure $3 a$ ). The best emulsion stability was registered in samples 7 (99.98\%) and 2 (99.97\%), where the sterilization time was much shorter. According to Glorieux et al. (2019), Kim et al. (2001), Santhi et al. (2017), the formation of a stable gel and a stable meat emulsion is influenced by a number of factors, such as heat treatment temperature and time, active acidity of the medium, etc., which corresponds to the lower potential for meat emulsion stabilization with the enhanced sterilization effect as established in this study. Perhaps thermal processing affects the structure of the carbon chains formed by the lentil flour and inulin gel added, hence

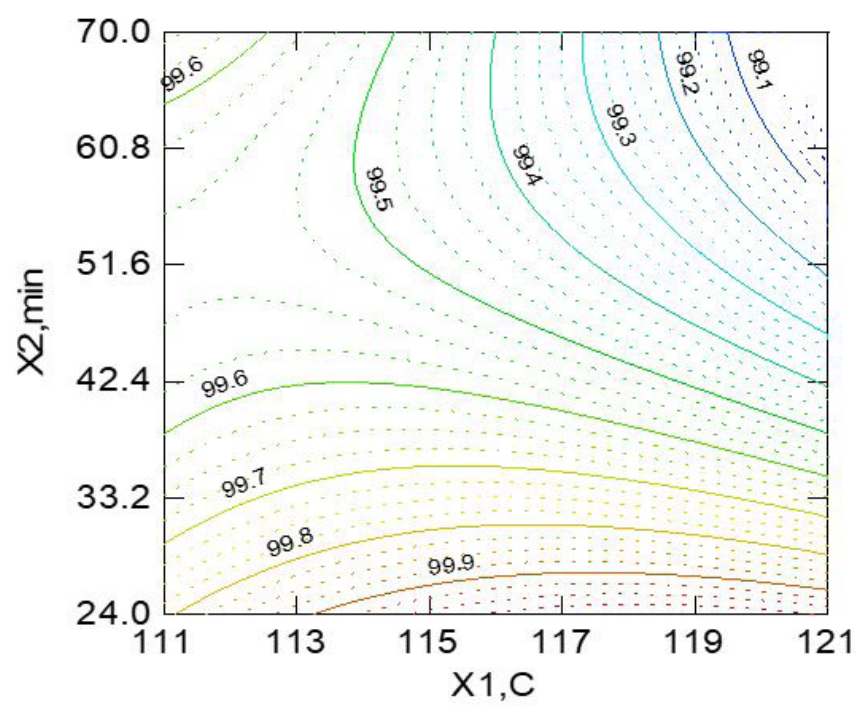

a

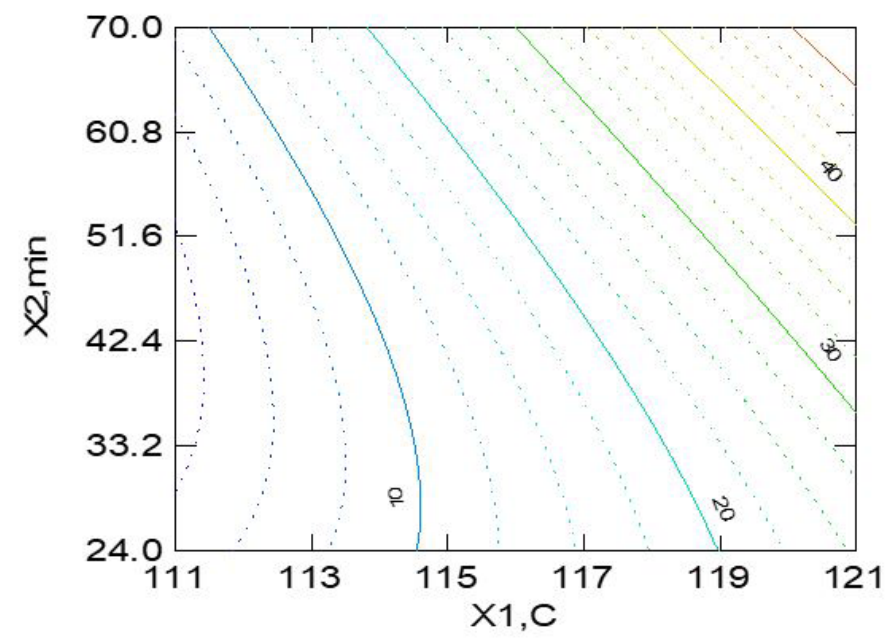

their capacity to stabilize meat emulsions (Barbut \& Youssef, 2016; Glorieux et al., 2019).

Apart from the emulsion capacity, there was also a marked dependence between the sterilization regime and the residual fructan content, including inulin, in the pâté samples (Table 1, Figure 3b). The inulin content decreased with the increase in temperature and sterilization time. As the holding time increased from 24 to $70 \mathrm{~min}$ and the temperature from 111 to $121^{\circ} \mathrm{C}$, the inulin-type fructan content was found to decrease from 1.67 to $0.59 \mathrm{~g} / 100 \mathrm{~g}$. These results corresponded well with the data reported by Böhm et al. (2005), Rueangwatcharin \& Wichienchot (2015), and Wang et al. (2009) indicating that heat treatment led to the decomposition of the long fructose chains to their monomers.

Fructooligosaccharide degradation was observed within a much lower heat treatment range of $60-100{ }^{\circ} \mathrm{C}$, and the rate of

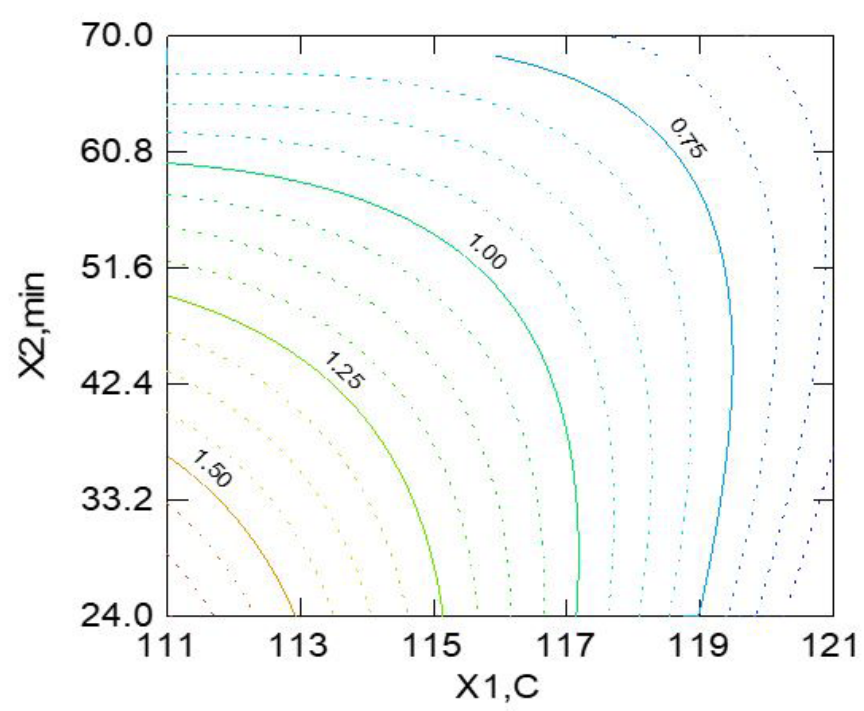

b

\section{c}

Figure 3. Effect of temperature $\left({ }^{\circ} \mathrm{C}\right)$ and holding time (min) on the emulsion stability - ES, \% (a), inulin-type fructan content - Fr, g/100 g) (b) and lethal effect, $\min (\mathrm{c})$. 
degradation depended on the treatment time and the active acidity of the medium (Glibowski \& Bukowska, 2011; Matusek et al., 2009). Thus, Huebner et al. (2008) reported that high temperature and low $\mathrm{pH}$ could cause partial degradation of these carbohydrates, and according to Böhm et al. (2005), these factors led to a significant reduction of the prebiotic potential of inulin. The amount of hydrolyzed saccharides is greater at a lower $\mathrm{pH}$ range from 2.7 to 4.2 , longer heating time and higher temperature. The degree of hydrolysis of fructooligosaccharides with high heating effects can even reach values of over $80 \%$ (Klewicki, 2007).

\section{Conclusion}

Demonstration of successful incorporation of functional ingredients into meat products is important for the developing and commercialization of new nutritionally designed foods. The mathematical models obtained describe with relatively high accuracy the effect of the independent variables temperature and holding time on the emulsion stability, fructan content and factual lethality of the sterilization process. The analysis of the results demonstrated that the more intensive sterilization regimes led to lower values of emulsion stability, which was more considerably affected by the holding time, as seen in the Pareto chart. In terms of the fructan content in the ready pâté samples after heat treatment, the Pareto chart shows that the linear effect of the temperature applied had a greater effect.

\section{References}

Álvarez, D., \& Barbut, S. (2013). Effect of inulin, $\beta$-glucan and their mixtures on emulsion stability, color and textural parameters of cooked meat batters. Meat Science, 94(3), 320-327. http://dx.doi. org/10.1016/j.meatsci.2013.02.011. PMid:23567131.

Barbut, S., \& Youssef, M. (2016). Effect of gradual heating and fat/ oil type on fat stability, texture, color, and microstructure of meat batters. Journal of Food Science, 81(9), C2199-C2205. http://dx.doi. org/10.1111/1750-3841.13420. PMid:27527510.

Berizi, E., Shekarforoush, S. S., Mohammadinezhad, S., Hosseinzadeh, S., \& Farahnaki, A. (2017). The use of inulin as fat replacer and its effect on texture and sensory properties of emulsion type sausages. Iranian Journal of Veterinary Research, 18(4), 253-257. PMid:29387097.

Böhm, A., Kaiser, I., Trebstein, A., \& Henle, T. (2005). Heat-induced degradation of inulin. European Food Research and Technology, 220(5-6), 466-471. http://dx.doi.org/10.1007/s00217-004-1098-8.

Briggs, M., Petersen, K., \& Kris-Etherton, P. (2017). Saturated fatty acids and cardiovascular disease: replacements for saturated fat to reduce cardiovascular risk. Health Care, 5(2), 29. PMid:28635680.

Cegielka, A., \& Tambor, K. (2012). Effect of inulin on the physical, chemical and sensory quality attributes of polish chicken burgers. Journal of Food Research, 1(1), 169-178. http://dx.doi.org/10.5539/jfr.v1n1p169.

Choi, Y. S., Choi, J. H., Han, D. J., Kim, H. Y., Lee, M. A., Kim, H. W., Jeong, J. Y., \& Kim, C. J. (2009). Characteristics of low-fat meat emulsion systems with pork fat replaced by vegetable oils and rice bran fiber. Meat Science, 82(2), 266-271. http://dx.doi.org/10.1016/j. meatsci.2009.01.019. PMid:20416740.

Choi, Y. S., Park, K. S., Kim, H. W., Hwang, K. E., Song, D. H., Choi, M. S., Lee, S. Y., Paik, H. D., \& Kim, C. J. (2013). Quality characteristics of reduced-fat frankfurters with pork fat replaced by sunflower seed oils and dietary fiber extracted from makgeolli lees. Meat Science, 93(3), 652658. http://dx.doi.org/10.1016/j.meatsci.2012.11.025. PMid:23273477.
Feiner, G. (2006). Cooked sausages. In G. Feiner, Meat products handbook: practical science and technology (pp. 239-285). Cambridge: Woodhead Publishing. http://dx.doi.org/10.1201/9781439824245.

Felisberto, M. H. F., Galvão, M. T. E. L., Picone, C. S. F., Cunha, R. L., \& Pollonio, M. A. R. (2015). Effect of prebiotic ingredients on the rheological properties and microstructure of reduced-sodium and low-fat meat emulsions. Lebensmittel-Wissenschaft + Technologie, 60(1), 148-155. http://dx.doi.org/10.1016/j.lwt.2014.08.004.

Glibowski, P., \& Bukowska, A. (2011). The effect of pH, temperature and heating time on inulin chemical stability. Acta Scientiarum Polonorum. Technologia Alimentaria, 10(2), 189-196. Retrieved from https://www.food.actapol.net/pub/5_2_2011.pdf

Glorieux, S., Steen, L., Van de Walle, D., Dewettinck, K., Foubert, I., \& Fraeye, I. (2019). Effect of meat type, animal fat type and cooking temperature on microstructural and macroscopic properties of cooked sausages. Food and Bioprocess Technology, 12(1), 16-26. http://dx.doi.org/10.1007/s11947-018-2190-6.

Holdsworth, S., \& Simpson, R. (2016). Thermal processing of packaged foods (3rd ed.). Cham: Springer International Publishing. http:// dx.doi.org/10.1007/978-3-319-24904-9.

Huebner, J., Wehling, R. L., Parkhurst, A., \& Hutkins, R. W. (2008). Effect of processing conditions on the prebiotic activity of commercial prebiotics. International Dairy Journal, 18(3), 287-293. http://dx.doi. org/10.1016/j.idairyj.2007.08.013.

Jozinović, A., Ačkar, D., Jokić, S., Babić, J., Balentić, J., Banožić, M., \& Šubarić, D. (2017). Optimisation of extrusion variables for the production of corn snack products enriched with defatted hemp cake. Czech Journal of Food Sciences, 35(6), 507-516. http://dx.doi. org/10.17221/83/2017-CJFS.

Keenan, D. F., Resconi, V. C., Kerry, J. P., \& Hamill, R. M. (2014). Modelling the influence of inulin as a fat substitute in comminuted meat products on their physico-chemical characteristics and eating quality using a mixture design approach. Meat Science, 96(3), 13841394. http://dx.doi.org/10.1016/j.meatsci.2013.11.025. PMid:24361558.

Kim, Y., Faqih, M. N., \& Wang, S. S. (2001). Factors affecting gel formation of inulin. Carbohydrate Polymers, 46(2), 135-145. http:// dx.doi.org/10.1016/S0144-8617(00)00296-4.

Klewicki, R. (2007). The stability of gal-polyols and oligosaccharides during pasteurization at a low $\mathrm{pH}$. Lebensmittel-Wissenschaft + Technologie, 40(7), 1259-1265. http://dx.doi.org/10.1016/j.lwt.2006.08.008.

Kumar, Y., Kairam, N., Ahmad, T., \& Yadav, D. N. (2016). Physico chemical, microstructural and sensory characteristics of low-fat meat emulsion containing aloe gel as potential fat replacer. International Journal of Food Science \& Technology, 51(2), 309-316. http://dx.doi. org/10.1111/ijfs.12957.

Latoch, A., Glibowski, P., \& Libera, J. (2016). The effect of replacing pork fat of inulin on the physicochemical and sensory quality of guinea fowl pate. Acta Scientiarum Polonorum. Technologia Alimentaria, 15(3), 311-320. http://dx.doi.org/10.17306/J.AFS.2016.3.30. PMid:28071030.

Luckose, F., Pandey, M., \& Radhakrishna, K. (2015). Development of low salt restructured chicken nugget by response surface methodology and its quality evaluation. International Food Research Journal, 22(6), 2403-2412. Retrieved from http://www.ifrj.upm.edu.my/22\%20(06)\%202015/(32).pdf

Mantzouridou, F., Spanou, A., \& Kiosseoglou, V. (2012). An inulin-based dressing emulsion as a potential probiotic food carrier. Food Research International, 46(1), 260-269. http://dx.doi.org/10.1016/j.foodres.2011.12.016.

Matusek, A., Merész, P., Le, T., \& Örsi, F. (2009). Effect of temperature and $\mathrm{pH}$ on the degradation of fructo-oligosaccharides. European Food Research and Technology, 228(3), 355-365. http://dx.doi. org/10.1007/s00217-008-0941-8. 
Morin, L. A., Temelli, F., \& McMullen, L. (2004). Interactions between meat proteins and barley (Hordeum spp.) $\beta$-glucan within a reducedfat breakfast sausage system. Meat Science, 68(3), 419-430. http:// dx.doi.org/10.1016/j.meatsci.2004.04.009. PMid:22062410.

Olmedilla-Alonso, B., Jiménez-Colmenero, F., \& Sánchez-Muniz, F. J. (2013). Development and assessment of healthy properties of meat and meat products designed as functional foods. Meat Science, 95(4), 919930. http://dx.doi.org/10.1016/j.meatsci.2013.03.030. PMid:23623320.

Pasichnyi, V., Ukrainets, A., Shvedyuk, D., Al-Hashimi, H. M., \& Matsuk, Y. (2017). Optimization of the canned poultry meat sterilization formula with hydrocolloids. Eastern-European Journal of Enterprise Technologies, 4(11), 29-34. http://dx.doi.org/10.15587/1729-4061.2017.108665.

Petkova, N., Ivanova, M., Todorova, M., Vlaseva, R., \& Denev, P. (2014). Spectrophotometric method for determination of inulin and fructooligosaccharides in lactic acid fermented dairy products. Acta Scientifica Naturalis, 1, 91-98. Retrieved from http://spisanie. shu.bg/wp-content/uploads/2017/04/ASN-2014-1.pdf

Pietrasik, Z., \& Li-Chan, E. (2002). Response surface methodology study on the effects of salt, microbial transglutaminase and heating temperature on pork batter gel properties. Food Research International, 35(4), 387-396. http://dx.doi.org/10.1016/S0963-9969(01)00133-8.

Riswanto, F., Rohman, A., Pramono, S., \& Martono, S. (2019). Application of response surface methodology as mathematical and statistical tools in natural product research. Journal of Applied Pharmaceutical Science, 9(10), 125-133. http://dx.doi.org/10.7324/JAPS.2019.91018.

Rueangwatcharin, U., \& Wichienchot, S. (2015). Development of functional canned and pouched tuna products added inulin for commercial production. Journal of Food Science and Technology, 52(8), 5093-5101. http://dx.doi.org/10.1007/s13197-014-1589-y. PMid:26243930.
Santhi, D., Kalaikannan, A., \& Sureshkumar, S. (2017). Factors influencing meat emulsion properties and product texture: a review. Critical Reviews in Food Science and Nutrition, 57(10), 2021-2027. http:// dx.doi.org/10.1080/10408398.2013.858027. PMid:25836950.

Shoaib, M., Shehzad, A., Omar, M., Rakha, A., Raza, H., Sharif, H., Shakeel, A., Ansari, A., \& Niazi, S. (2016). Inulin: Properties, health benefits and food applications. Carbohydrate Polymers, 147, 444-454. http://dx.doi.org/10.1016/j.carbpol.2016.04.020. PMid:27178951.

Silva-Vazquez, R., Flores-Giron, E., Quintero-Ramos, A., Hume, M. E., \& Mendez-Zamora, G. (2018). Effect of inulin and pectin on physicochemical characteristics and emulsion stability of meat batters. CYTA: Journal of Food, 16(1), 306-310. http://dx.doi.org/1 0.1080/19476337.2017.1403490.

Souza, C., Bellucci, E., Lorenzo, J., \& Barretto, A. (2019). Low-fat Brazilian cooked sausage-Paio - with added oat fiber and inulin as a fat substitute: effect on the technological properties and sensory acceptance. Food Science and Technology, 39(1, Suppl. 1), 295-303. http://dx.doi.org/10.1590/fst.03618.

Wang, J., Sun, B., Cao, Y., Tian, Y., \& Wang, C. (2009). Enzymatic preparation of wheat bran xylooligosaccharides and their stability during pasteurization and autoclave sterilization at low $\mathrm{pH}$. Carbohydrate Polymers, 77(4), 816-821. http://dx.doi.org/10.1016/j. carbpol.2009.03.005.

Zorba, O., Gokalp, H. Y., Yetim, H., \& Ockerman, H. W. (1993). Model system evaluations of the effects of different levels of $\mathrm{K}_{2} \mathrm{HPO}_{4}$ $\mathrm{NaCl}$ and oil temperature on emulsion stability and viscosity of fresh and frozen Turkish style meat emulsions. Meat Science, 34(2), 145-161. http://dx.doi.org/10.1016/0309-1740(93)90024-C. PMid:22060660. 